\title{
CPRMethicillin resistant coagulase-negative staphylococci isolated from South Korean ducks exhibiting tremor
}

Jee Eun Han ${ }^{1+}$, Sun Young Hwang ${ }^{1 \dagger}$, Ji Hyung Kim² ${ }^{2}$ Sang Phil Shin ${ }^{1}$, Jin Woo Jun ${ }^{1}$, Ji Young Chai ${ }^{3}$, Yong Ho Park ${ }^{1}$ and Se Chang Park ${ }^{1 *}$

\begin{abstract}
Background: We describe coagulase-negative staphylococci (CoNS) isolates collected from ducklings exhibiting tremor in South Korea over the period of 2010 to 2011. Screening of antimicrobial susceptibility and analysis of SCCmec elements of CoNS were also investigated.

Results: Staphylococcus cohnii was the most frequent staphylococcus (9 isolates) and S. sciuri (4 isolates), S. lentus (3 isolate), S. simulans (1 isolate) and S. epidermidis ( 1 isolate) were also detected. Among the 15 antimicrobials tested in this study, resistance against oxacillin (15 isolates, 83.3\%) was most frequently observed, but only one isolate (SNUDS-1) possessed mecA. This isolate was shown to possess SCCmec type III; the type $3 \mathrm{ccr}$ complex and the class A mec complex.

Conclusions: Based on these results, isolate SNUDS-1 was shown to possess SCCmec type III; the type 3 ccr complex and the class A mec complex. Although the SCCmec type III is not predominant in human, MR-CoNS (Methicillin resistance Coagulase-negative staphylococci) in food animals should be monitored to prevent the dissemination of antimicrobial resistance genes and resistant pathogens to the community.
\end{abstract}

Keywords: Methicillin resistance, Coagulase negative staphylococci, Duck, SCCmec complex

\section{Background}

Coagulase-negative staphylococci (CoNS) are commensal bacterial species and opportunistic pathogens that can cause infections in human and animals [1]. CoNS are considered a reservoir of antimicrobial resistance since they usually possess various antimicrobial resistance-associated determinants [2]. Methicillin resistance (MR) is one of the most serious public health issues and can increase both the failure rate of antibiotic therapy and mortality rates in human diseases [3]. MR-CoNS were also found in animals with clinical infections. Van Duijkeren et al. detected MR Staphylococcus haemolyticus from cystitis, rhinitis, bronchitis and pyoderma in cats and dogs [4]. Fessler et al. [5] isolated different MR-CoNS species from bovine mastitis.

\footnotetext{
* Correspondence: parksec@snu.ac.kr

${ }^{\dagger}$ Equal contributors

${ }^{1}$ College of Veterinary Medicine and Research Institute for Veterinary Science, Seoul National University, Seoul 151-742, Republic of Korea

Full list of author information is available at the end of the article
}

However, MR-CoNS were rarely reported in avian disease, but rather usually reported from healthy birds [6].

The determinant of MR is mecA, which encodes a penicillin-biinding protein (PBP2a) that has a low affinity to beta-lactam antibiotics. This gene is located on the staphyloccoccal cassette chromosome mec (SCCmec) element, a genomic island ubiquitously disseminated among staphylococci [7]. The SCCmec element carries two essential parts, the mec gene complex consist of mecA and its regulator genes and the cassette chromosome recombinase ( $c c r$ ) complex composed of recombinase genes. The regions other than those two complexes are designated junkyard ( $J$ ) regions. The SCCmec element is typed by its mecA and $c c r$ complex and the J regions, which define the subtype of the element [8]. Although the origin of the SCCmec elements remains unknown, it has been suggested that the SCCmec elements evolved in CoNS and then were horizontally transferred among different Staphylococcus species [9]. In particular, S. fleurettii, S. sciuri and S. vitulinus are

\section{Biomed Central}


suggested as a origin of the mecA element of SCCmec elements [10].

There is concern that CoNS in food animals can be disseminated to humans via the food production chain [11]. Furthermore, the SCCmec elements in MR-CoNS of food animals are transmissible to humans via food [12]. Therefore, screening the antimicrobial resistance and analysis of SCCmec elements of CoNS in food animals is important for public health. Despite the importance of such a screen, many researchers have only focused on MR S. aureus (MRSA), the most pathogenic staphylococci, and few data are available for MR-CoNS among the ducks. In this study, we isolated CoNS isolates from ducklings and investigated their antimicrobial susceptibility. In addition, the SCCmec element of the isolated MR-CoNS isolate was analyzed.

\section{Methods}

\section{Bacterial isolation}

Samples were collected from ducklings exhibiting clinical signs of listlessness, ataxia, tremors of the head and legs, and coma, originated from 4 different farms in South Korea over the period of 2010 to 2011. Swabs from the organs were streaked on $5 \%$ sheep blood agar and incubated for $24-48 \mathrm{hr}$ at $37^{\circ} \mathrm{C}$. After incubation, among the representative colony of the plate, one staphylococci-like colony was collected as described by Moon et al. [13]. The isolates were stored in tryptic soy broth (TSB; Difco, USA) with $10 \%$ glycerol at $-80^{\circ} \mathrm{C}$ until used. College of Veterinary Medicine is certificated institution for experiments using laboratory animals and we carried out the experiment using ethical way. In this experiment, moribund samples were anesthetized according to the established rules approved by the Seoul National University Institutional Animal Care and Use Committee.

\section{DNA extraction}

Bacterial stock was sub-cultured on tryptic soy agar (TSA; Difco) at for $24-48 \mathrm{hr}$ at $37^{\circ} \mathrm{C}$ and then single colony was sub-cultured in TSB for DNA extraction. Chromosomal DNA isolation was performed using the Wizard genomic DNA purification kit (Promega, Madison, USA) according to the manufacture's instruction except using lysostaphin $(0.5 \mathrm{mg} / \mathrm{ml})$ and RNase $(0.3 \mathrm{mg} / \mathrm{ml})$ for the lysis step.

\section{Bacterial identification}

Bacterial species were confirmed by species-specific polymerase chain reaction (PCR) and sequencing analysis of the sodA gene for CNS as described by Poyart et al. [14]. Sequencing was carried out by the Macrogen Genomic Division, Korea. Analyzed sequence was aligned with full genome sequenced Staphylococcus species using the NCBI BLAST (http://blast.ncbi.nlm.nih.gov/) to confirm their species when the similarity was over $99 \%$.

\section{Antimicrobial susceptibility test}

Antimicrobial susceptibility tests for staphylococcal isolates were carried out using the disk diffusion method according to the Clinical Laboratory Standard Institute guidelines [15,16]. Fifteen antimicrobials were used: cefoxitin, ciprofloxacin, clindamycin, erythromycin, gentamicin, linezolid, mupirocin, oxacillin, penicillin, quinupristin/dalfopristin, rifampicin, teicoplanin, tetracycline, trimethoprim/sulfamethoxazole and vancomycin. The minimum inhibitory concentration (MIC) of oxacillin was determined using the broth microdilution method $[15,16]$. Isolates that had a MIC $\geq 0.5 \mu \mathrm{g} / \mathrm{ml}$ were defined as oxacillin resistant isolates. For quality control, $S$. aureus ATCC25923 and S. aureus ATCC29213 were used for the disc diffusion tests and the microdilution test respectively.

\section{Multiplex PCR}

For detection of mecA, PCR followed by sequencing was performed as described by Zhang et al. [17]. For SCCmec element typing, the mec gene and ccr complexes were identified by multiplex PCR and subsequent sequencing as described by Kondo et al. [18], who detected the class $\mathrm{A}, \mathrm{B}, \mathrm{C} 1$ and $\mathrm{C} 2$ mec complex. Also, $c c r A, c c r B$ and $c c r C$ were detected as descrbed by Zong et al. [19] and Zong and $\mathrm{Lu} \mathrm{[20]} \mathrm{and} \mathrm{Pi}$ et al. [21] (Table 1).

\section{Results}

\section{Isolation and identification of CoNS}

Organ samples (trachea, lung and brain tissue) were collected from 55 ducklings displaying clinical signs of tremors. A total of 18 isolates were collected from different animals and identified as CoNS (Table 2). The staphylococcal isolation rate was $32.7 \%$ and the most frequently isolated species was $S$. cohnii.

\section{Antimicrobial susceptibility and detection of mecA}

Among the 15 antimicrobials tested in this study, resistance against oxacillin (15 isolates, 83.3\%), ciprofloxacin (12 isolates, 66.7\%) and cefoxitin (7 isolates, 38.9\%) were most frequently observed (Table 2). Among the 15 oxacillin resistant isolates, 11 isolates showed resistance against more than three antimicrobials other than oxacillin. Despite the high oxacillin resistance rate, only one isolate (SNUDS-1, S. sciuri) carried mecA (Table 2). All isolates were susceptible against gentamicin, linezolid, mupirocin, quinopristin/dalfopristin, teicoplanin, trimethoprim/sulfamethoxazole and vancomycin.

\section{SCCmec typing}

SCCmec typing was performed on SNUDS-1. The amplicon size of the mec complex was 1,963 bp and $804 \mathrm{bp}$ when the mA7, mI6, IS7 and IS2 (iS-2) primers were 
Table 1 Primers used in this study

\begin{tabular}{|c|c|c|c|}
\hline Primer & Nucleotide sequence $^{*}\left(5^{\prime}-3^{\prime}\right)$ & Target location & Reference \\
\hline \multicolumn{4}{|l|}{ sodA } \\
\hline d1 & CCITAYICITAYGAYGCIYTIGARCC & $\operatorname{sod} A$ & {$[14]$} \\
\hline d2 & ARRTARTAIGCRTGYTCCCAIACRTC & & \\
\hline \multicolumn{4}{|c|}{ mec complex } \\
\hline mA7 & ATATACCAAACCCGACAACTACA & mecA & {$[18]$} \\
\hline $\mathrm{ml6}$ & CATAACTTCCCATTCTGCAGATG & med & \\
\hline IS7 & ATGCTTAATGATAGCATCCGAATG & IS1272 & \\
\hline IS2 (iS-2) & TGAGGTTATTCAGATATTTCGATGT & 15431 & \\
\hline \multicolumn{4}{|c|}{ ccr complex } \\
\hline ccrA-UF1 & AATGTGAHGTATTATGTTGYTA & CCrA & {$[20]$} \\
\hline ccrA-UR1 & GGTTCATTITTDAARTAGAT & & \\
\hline ccrA-UF2 & AYTHCATCGYAAYYTGAAAAA & CCrA & [19] \\
\hline ccrA-UR2 & ACGDCCACARTAGTTAGGRTT & & \\
\hline ccrA_up & TGCATTCATGTTTTGAGGAC & CCrA & {$[21]$} \\
\hline ccrA_dw & CAATGTGACGTATTGTGTTG & & \\
\hline ccrB-UF1 & CGTGTATCAACDGAAATVCAA & $\operatorname{ccr} B$ & {$[20]$} \\
\hline ccrB-UR1 & CTITATCACTITGAYWATTTC & & \\
\hline ccrB_up & GTTCCTITACCATGGACTTG & $C C r B$ & {$[21]$} \\
\hline ccrB_dw & CTAGAAGGCTACTATCAAGG & & \\
\hline ccrC-UF1 & GCAATGAAACGTCTATTACAA & $\mathrm{ccrCl}$ & [19] \\
\hline ccrC-UR1 & TTTCATCRATAACYAAATCA & & \\
\hline $28-24$ & GGAACAATCAGAGCGTGGA & $\operatorname{ccrC2}$ & {$[20]$} \\
\hline $28-26$ & ACGTTTCACAGCCCAATTTT & & \\
\hline
\end{tabular}

"D: A, G or T; H: H, C or T; M: A or C; R: A or G; W: A or T; Y: C or T; V: A, C or G.

used. According to Kondo et al. [18], this means SNUDS-1 carried mecA, mecI and IS431 upstream of $m e c A$ but no IS1272. These features showed that SNUDS-1 possessed the class A mec complex.

The ccrA gene was successfully amplified from the genomic DNA of SNUDS-1 using primers for ccrA-UF1 and -UR1, ccrA-UF2 and -UR2 and ccrA_up and _dw pairs. The $c c r B$ gene was also amplified with primers for ccrB-UF1 and -UR1 and ccrB_up and _dw pairs. However, the amplified products obtained using the primers for ccrC-UF1 and -UR1 and 28-24 and -26 pairs were determined as non-specific products by sequencing analysis. The amplified products obtained using ccrA-UF1 and -UR1 (1095 bp of final product) and ccrB-UF1 and -UR1 (1047 bp of final product) primers were sequenced and blast searched against other $c c r$ genes using GenBank (http://blast.ncbi.nlm.nih.gov). The ccrA gene product was similar to the $c c r A 3$ from the $S$. cohnii strain WC28 (Acc. No. GU370073.2) with a similarity of 94\%. The sequence of the amplified $c c r B$ showed the closest match to the sequences of the $c c r B 3$ of $S$. sciuri strain MCS 24 (Acc. No. AB587080.1) with a similarity of 95\%. Based on the combined results presented above, the isolate
SNUDS-1 was shown to possess SCCmec type III; the type $3 \mathrm{ccr}$ complex and the class A mec complex [19].

\section{Discussion}

CoNS have been frequently detected from food animals $[12,22]$, but hardly reported in ducklings. In this study, staphylococci isolated from the organs of duckings with tremors, such as the brain, were investigated. Central nervous system signs in avian species are usually caused by virus and mycotoxin [23]. This can be explained by the fact that there is an unusual cause of tremors from septicaemia and systemic infection caused by bacteria and candida [24,25]. Also, the staphylococci isolated in this study might be result from a secondary infection of predisposed viral diseases. Other bacterial species except Staphylococci were not isolated from organ samples.

Antimicrobial resistant of food animals is a serious public health problem because of the possibility of dissemination of the antimicrobial resistant bacteria to humans via food [26]. In Korea, extensive studies were performed to investigate the methicillin resistance in major food animals such as bovine raw milk, beef, pork and chicken meat $[27,28]$. For ducks, however, there are 
Table 2 Coagulase-negative staphylococcal isolates isolated from duck with tremor

\begin{tabular}{|c|c|c|c|c|c|c|}
\hline \multirow[t]{2}{*}{ Isolate } & \multirow[t]{2}{*}{ Organ } & \multirow[t]{2}{*}{ Species } & \multirow[t]{2}{*}{ mecA } & \multirow{2}{*}{$\begin{array}{l}\text { Antimicrobial } \\
\text { resistant pattern }\end{array}$} & \multicolumn{2}{|l|}{ Oxacillin } \\
\hline & & & & & MIC $(\mu \mathrm{g} / \mathrm{ml})$ & Interpretation \\
\hline SNUDS-2 & Brain & S. cohnii & - & Cef-Pen-Oxa-Cip-SxT & $\geq 4$ & $R$ \\
\hline SNUDS-3 & Brain & S. cohnii & - & Cef-Pen-Oxa-Cip & $\geq 4$ & $\mathrm{R}$ \\
\hline SNUDS-4 & Brain & S. cohnii & - & Cef-Pen-Oxa-Cip & $\geq 4$ & $\mathrm{R}$ \\
\hline SNUDS-10 & Brain & S. cohnii & - & Oxa-Сip & 0.5 & $\mathrm{R}$ \\
\hline SNUDS-1 & Brain & S. sciuri & + & Oxa-Cip-Tet & $\geq 4$ & $\mathrm{R}$ \\
\hline SNUDS-11 & Brain & S. simulans & - & Cip-Cli-SxT & $\leq 0.25$ & S \\
\hline SNUDS-6 & Brain & S. cohnii & - & Cef-Pen-Oxa-Tet & $\geq 4$ & $\mathrm{R}$ \\
\hline SNUDS-7 & Brain & S. cohnii & - & Tet & $\leq 0.25$ & S \\
\hline SNUDS-8 & Trachea & S. cohnii & - & Cef-Pen-Oxa-Tet & 2 & $R$ \\
\hline SNUDS-5 & Lung & S. lentus & - & Oxa-Cli & 0.5 & $\mathrm{R}$ \\
\hline SNUDS-9 & Brain & S. sciuri & - & Cef-Pen-Oxa-Tet & 2 & $\mathrm{R}$ \\
\hline SNUDS-13 & Brain & S. cohnii & - & Oxa-Сip & 0.5 & $\mathrm{R}$ \\
\hline SNUDS-14 & Lung & S. cohnii & - & Oxa-Cip-Tet-SxT & 0.5 & R \\
\hline SNUDS-12 & Brain & S. lentus & - & Oxa-Cip-Cli-QDA -SxT & 0.5 & $\mathrm{R}$ \\
\hline SNUDS-15 & Brain & S. lentus & - & Cef-Pen-Oxa-Cip-Tet-SxT & 2 & $\mathrm{R}$ \\
\hline SNUDS-16 & Trachea & S. epidermidis & - & - & $\leq 0.25$ & S \\
\hline SNUDS-17 & Brain & S. sciuri & - & Oxa-Cip-Ery-Cli & 0.5 & $\mathrm{R}$ \\
\hline SNUDS-18 & Brain & S. sciuri & - & Oxa-Cip-Ery-Cli-Tet-SxT & 2 & $\mathrm{R}$ \\
\hline
\end{tabular}

"Cef: cefoxitin; Pen: penicillin; Oxa: oxacillin; Cip: ciprofloxacin; SxT: sulphamethoxazole/trimethoprim; Tet: tetracycline; Cli: clindamycin; QDA: quinupristindalfopristin; Ery: erythromycin.

few studies although the South Korean duck industry has been growing fast recently [29]. Moreover, the possibility of spread from ducks to humans may be higher than that from chickens due to unapparent infections and poor sanitary conditions [30].

In this study, mecA was detected from only one out of 15 isolates showing oxacillin resistant phenotype. Although 10 of the mecA-negative oxacillin resistant isolates had MIC $\leq 2 \mu \mathrm{g} / \mathrm{ml}, 4$ isolates had MICs over $4 \mu \mathrm{g} / \mathrm{ml}$ as the $m e c A$ positive isolate. There are unusual MR-CoNS that have a resistance mechanism other than the production of PBP2a, which have been reported as borderline methicillinresistant strains [31]. Most of them are resistant to oxacillin due to their plasmid-borne determinants, including hyperproduced penicillinases, genes conferring resistance to cadmium, or other gene products [32,33]. It is also possible that these mecA-negative oxacillin resistant CoNS possessed mecA alleles, which could not be detected by the primers used in this study. According to Monecke et al., many CoNS strains of animal origin show diversity in mecA sequences and have a different impact on $\beta$-lactam resistance [34].

In this study, the mecA carrying isolate, SNUDS-1 was shown to be of the SCCmec type III. According to Zong et al. [18], the common types of SCCmec in MR-CoNS are II, III, IV and V and Type III is common and widely distributed in a variety staphylococcal species. There are plenty of $c c r$ variants with nucleotide differences and the allotype is assigned based on $85 \%$ identity. Since many new types of ccr allotypes have been reported, especially in MR-CoNS, multiple pairs of primers for the $c c r$ genes should be used to maximize the possibility of detection [35].

Although the SCCmec type III is not the predominant type in human, MR-CoNS in food animals should be monitored to prevent the dissemination of antimicrobial resistance genes and resistant pathogens to the community.

\section{Conclusions}

From this study, CoNS isolates from ducklings and their antimicrobial susceptibility were investigated. Resistance against oxacillin, ciprofloxacin and cefoxitin were most frequently observed and one strain carried the mecA gene which corresponds to a class A mec complex by SCCmec typing. Because of the possibility of dissemination of the antimicrobial resistant bacteria to human via the food processing chains, screening the antimicrobial resistance bacteria in duck industry should be performed further.

\section{Abbreviations}

Ccr: Cassette chromosome recombinase; CoNS: Coagulase-negative staphylococci; J: Junkyard; PBP2a: Penicillin-biinding protein;

SCCmec: Staphyloccoccal cassette chromosome mec; TSB: Tryptic soy broth.

\section{Competing interests}

The authors declare that they have no competing interests. 


\section{Authors' contributions}

JEH has been involved in drafting the article and carried out collection of the samples and interpretation of the data. SYH conceived the study and participated in its design and coordination, and helped to draft the article. JJK participated in the discussion on the study design. SPS and JWJ involved collection of the samples. JYC, YHP and SCP helped to draft the manuscript. All authors read and approved the final manuscript. All authors read and approved the final article.

\section{Acknowledgements}

This research was supported by Basic Science Research Program through the National Research Foundation of Korea (NRF) funded by the Ministry of Education (2013R1A1A2006794) and Bio-industry Technology Development Program, Ministry for Food, Agriculture, Forestry and Fisheries (IPET 110069-2), Republic of Korea.

\section{Author details}

${ }^{1}$ College of Veterinary Medicine and Research Institute for Veterinary Science, Seoul National University, Seoul 151-742, Republic of Korea. ${ }^{2}$ Korea Institute of Ocean Science \& Technology, Ansan 426-744, Republic of Korea. ${ }^{3}$ Department of Rheumatology, Bundang Jesaeng Hospital, Seongnam 463-774, Republic of Korea.

Received: 5 June 2013 Accepted: 3 December 2013

Published: 11 December 2013

\section{References}

1. Kloos WE, Bannerman TL: Update on clinical significance of coagulasenegative staphylococci. Clin Microbiol Rev 1994, 7:117-140.

2. Bally M, Dendukuri N, Sinclair A, Ahern SP, Poisson M, Brophy J: A network meta-analysis of antibiotics for treatment of hospitalised patients with suspected or proven meticillin-resistant Staphylococcus aureus infection. Int J Antimicrob Agents 2012, 40:479-495.

3. Ben Zakour NL, Sturdevant DE, Even S, Guinane CM, Barbey C, Alves PD, Cochet MF, Gautier M, Otto M, Fitzgerald JR, Le Loir Y: Genome-wide analysis of ruminant Staphylococcus aureus reveals diversification of the core genome. J Bacterio/ 2008, 190:6302-6317.

4. Van Duijkeren E, Box ATA, Heck MEOC, Wannet WJB, Fluit AC: Methicillinresistant staphylococci isolated from animals. Vet Microbiol 2004, 103:91-97.

5. Fessler AT, Billerbeck C, Kadlec K, Schwarz S: Identification and characterization of methicillin-resistant coagulase-negative staphylococci from bovine mastitis. J Antimicrob Chemother 2010, 65:1576-1582.

6. Kawano J, Shimizu A, Saitoh Y, Yagi M, Saito T, Okamoto R: Isolation of methicillin-resistant coagulase-negative staphylococci from chickens. J Clin Microbiol 1996, 34:2072-2077.

7. Baba T, Takeuchi F, Kuroda M, Yuzawa H, Aoki K, Oguchi A, Nagai Y, Iwama N, Asano K, Naimi T, Kuroda H, Cui L, Yamamoto K, Hiramatsu K: Genome and virulence determinants of high virulence communityacquired MRSA. Lancet 2002, 359:1819-1827.

8. Oliveira DC, Tomasz A, De Lencastre H: The evolution of pandemic clones of methicillin-resistant Staphylococcus aureus: identification of two ancestral genetic backgrounds and the associated mec elements. Microb Drug Resist 2001, 7:349-361.

9. Bastos MCF, Mondino PJJ, Azevedo MLB, Santos KRN, Giambiagi-deMarval M: Molecular characterization and transfer among Staphylococcus strains of a plasmid conferring high-level resistance to mupirocin. Eur J Clin Microbiol Infect Dis 1999, 18:393-398.

10. Tsubakishita S, Kuwahara-Arai K, Sasaki T, Hiramatsu K: Origin and molecular evolution of the determinant of methicillin resistance in staphylococci. Antimicrob Agents Chemother 2010, 54:4352-4359.

11. Juhasz-Kaszanyitzky E, Janosi S, Somogyi P, Dan A, van der Graaf-van Bloois $L$, van Duijkeren E, Wagenaar JA: MRSA transmission between cows and humans. Emerg Infect Dis 2007, 13:630-632.

12. Huber H, Ziegler D, Pfluger V, Vogel G, Zweifel C, Stephan R: Prevalence and characteristics of methicillin-resistant coagulase-negative staphylococci from livestock, chicken carcasses, bulk tank milk, minced meat, and contact persons. BMC Vet Res 2011, 7:6.

13. Moon BY, Youn JH, Shin S, Hwang SY, Park YH: Genetic and phenotypic characterization of methicillin- resistant staphylococci isolated from veterinary hospitals in South Korea. J Vet Diagn Invest 2012, 24:489-498.
14. Poyart C, Berche P, Trieu-Cuot P: Characterization of superoxide dismutase genes from gram-positive bacteria by polymerase chain reaction using degenerate primers. FEMS Microbiol Lett 1995, 131:41-45.

15. Clinical and Laboratory Standards Institute: Performance Standards for Antimicrobial Disk and Dilution Susceptibility Tests for Bacteria Isolated from Animals. 3rd edition. Wayne, PA, USA: approved standard M31-A3. CLSI; 2008.

16. Clinical and Laboratory Standards Institute: Performance Standards for Antimicrobial Susceptibility Testing; Twenty-Third Informational Supplement. Wayne, PA, USA: CLSI; 2012.

17. Zhang K, Sparling J, Chow BL, Elsayed S, Hussain Z, Church DL, Gregson DB, Louie T, Conly JM: New quadriplex PCR assay for detection of methicillin and mupirocin resistance and simultaneous discrimination of Staphylococcus aureus from coagulase-negative staphylococci. J Clin Microbiol 2004, 42:4947-4955.

18. Kondo $Y$, Ito T, Ma XX, Watanabe S, Kreiswirth BN, Etienne J, Hiramatsu K: Combination of multiplex PCRs for staphylococcal cassette chromosome mec type assignment: rapid identification system for mec, $\mathrm{ccr}$, and major differences in junkyard regions. Antimicrob Agents Chemother 2007, 51:264-274

19. Zong Z, Peng C, Lu X: Diversity of SCCmec elements in methicillinresistant coagulase-negative staphylococci clinical isolates. PLoS One 2011, 6:e20191.

20. Zong Z, Lu X: Characterization of a new SCCmec element in Staphylococcus cohnii. PLoS One 2010, 5:e14016.

21. Pi B, Yu M, Chen Y, Yu Y, Li L: Distribution of the ACME-arcA gene among meticillin-resistant Staphylococcus haemolyticus and identification of a novel ccr allotype in ACME-arcA-positive isolates. J Med Microbiol 2009, 58:731-736

22. Unal N, Cinar OD: Detection of stapylococcal enterotoxin, methicillinresistant and Panton-Valentine leukocidin genes in coagulase-negative staphylococci isolated from cows and ewes with subclinical mastitis. Trop Anim Health Prod 2012, 44:369-375.

23. Cole RJ, Kirksey JW, Moore JH, Blankenship BR, Diener UL, Davis ND: Tremorgenic toxin from Penicillium verruculosum. Appl Microbiol 1972, 24:248-256.

24. De Herdt P, Ducatelle R, Haesebrouck F, Devriese LA, De Groote B, Roels S: An unusual outbreak of Streptococcus bovis septicaemia in racing pigeons (Columba livia). Vet Rec 1994, 134:42-43.

25. Wyatt RD, Simmons DG, Hamilton PB: Induced systemic candidiasis in young broiler chickens. Avian Dis 1975, 19:533-543.

26. Capita R, Alonso-Calleja C: Antibiotic-resistant bacteria: a challenge for the food industry. Crit Rev Food Sci Nutr 2013, 53:11-48.

27. Lim SK, Nam HM, Park HJ, Lee HS, Choi MJ, Jung SC, Lee JY, Kim YC, Song SW, Wee SH: Prevalence and characterization of methicillin-resistant Staphylococcus aureus in raw meat in Korea. J Microbiol Biotechnol 2010, 20:775-778.

28. Moon JS, Lee AR, Kang HM, Lee ES, Kim MN, Paik YH, Park YH, Joo YS, Koo HC: Phenotypic and genetic antibiogram of methicillin-resistant staphylococci isolated from bovine mastitis in Korea. J Dairy Sci 2007, 90:1176-1185.

29. FAO FaAO. FAOSTAT on download data in production of live animals (duck) in 2012. http://faostat3.fao.org/home/index]

30. Cha SY, Kang M, Yoon RH, Park CK, Moon OK, Jang HK: Prevalence and antimicrobial susceptibility of Salmonella isolates in Pekin ducks from South Korea. Comp Immunol Microbiol Infect Dis 2013, 36:473-479.

31. Suzuki E, Hiramatsu K, Yokota T: Survey of methicillin-resistant clinical strains of coagulase-negative staphylococci for mecA gene distribution. Antimicrob Agents Chemother 1992, 36:429-434.

32. Massidda $\mathrm{O}$, Montanari MP, Mingoia M, Varaldo PE: Borderline methicillinsusceptible Staphylococcus aureus strains have more in common than reduced susceptibility to penicillase-resistant penicillins. Antimicrob Agents Chemother 1996, 40:2769-2774.

33. Massidda O, Mingoia M, Fadda D, Whalen MB, Montanari MP, Varaldo PE: Analysis of the beta-lactamase plasmid of borderline methicillinsusceptible Staphylococcus aureus: focus on bla complex genes and cadmium resistance determinants cadD and cadX. Plasmid 2006, 55:114-127.

34. Monecke S, Muller E, Schwarz S, Hotzel H, Ehricht R: Rapid microarray based identification of different mecA alleles in staphylococci. Antimicrob Agents Chemother 2012, 56:5547-5554. 
35. Urushibara N, Paul SK, Hossain MA, Kawaguchiya M, Kobayashi N: Analysis of Staphylococcal cassette chromosome mec in Staphylococcus haemolyticus and Staphylococcus sciuri: identification of a novel ccr gene complex with a newly identified ccrA allotype (ccrA7). Microb Drug Resist 2011, 17:291-297.

doi:10.1186/1751-0147-55-88

Cite this article as: Han et al.: CPRMethicillin resistant coagulase-negative staphylococci isolated from South Korean ducks exhibiting tremor. Acta Veterinaria Scandinavica 2013 55:88.

\section{Submit your next manuscript to BioMed Central} and take full advantage of:

- Convenient online submission

- Thorough peer review

- No space constraints or color figure charges

- Immediate publication on acceptance

- Inclusion in PubMed, CAS, Scopus and Google Scholar

- Research which is freely available for redistribution 